\title{
Evaluation of two viral isolates as a potential biocontrol agent against the Egyptian cotton leafworm, Spodoptera littoralis (Boisd.) (Lepidoptera: Noctuidae)
}

Wael Elmenofy ${ }^{1 *}$ D, Reda Salem, Engy Osman³ , Norhan Yasser ${ }^{1}$, Alaa Abdelmawgod², Maryam Saleh², Aya Zaki Engy Hanafy², Sally Tamim², Salma Amin², Aml El-Bakry², Aya El-Sayed² and Lamiaa El-Gaied ${ }^{1}$

\begin{abstract}
Two different Spodoptera littoralis (Boisd.) (Lepidoptera: Noctuidae) nucleopolyhedrovirus (SpliNPV) isolates were obtained from natural infected S. littoralis larvae in Egypt. The phylogenetic analysis of the partial nucleotide sequence of the polyhedrin gene (polh) showed that both isolates, Spli-6 and Spli-7, were closed and had a common ancestor with S. littoralis NPV isolate 1263 polyhedrin gene, partial coding sequence with accession number AGE90003.1 that belongs to group II NPVs. This indicates that the natural host of Spli-6 and Spli-7 must be $S$. littoralis. The virulence of these isolates was tested against $S$. littoralis larvae in a laboratory. The $\mathrm{LC}_{50}$ against $1 \mathrm{st}$ instar larvae was significantly different, $3 \times 10^{4} \mathrm{OBs} / \mathrm{ml}$ and $9.5 \times 10^{4} \mathrm{OBs} / \mathrm{ml}$ for Spli-6 and Spli-7, respectively. However, the $\mathrm{LC}_{50}$ for the mixed infection of both isolates was $3.9 \times 10^{4} \mathrm{OBs} / \mathrm{ml}$. On the other hand, the $\mathrm{ST}_{50}$ was $96 \mathrm{~h}$ for both isolates, while it was $120 \mathrm{~h}$ for the mixed infection, which was higher than that observed of each single isolate. Upon digestion of viral DNA with Scal endonuclease, the restriction profile showed one more fragment of about $\sim 25 \mathrm{kbp}$ and 3 fragments of about $\sim 19, \sim 5.8$, and $\sim 5.3 \mathrm{kbp}$ in Spli-7 isolate compared to Spli-6 as well as the reference strain SpliNPV-AN1956. The differences in the fragment size and number suggest the existence of genotypic variants between both isolates. Spli-6 and Spli-7 proved to possess promising insecticidal properties for the development of virus-based biopesticide for the control of $S$. littoralis.
\end{abstract}

Keywords: Nucleopolyhedrovirus, Spodoptera littoralis, Bioassay, Restriction pattern

\section{Background}

The cotton leafworm, Spodoptera littoralis (Boisd.) (Lepidoptera: Noctuidae), is one of the most economic insect pests in Egyptian fields. In Egypt, it is considered as a destructive pest that causes economic losses not only for the cotton plants but also for other crops and vegetables (Hosny et al. 1986), orchard trees, and ornamentals (Mohamed et al. 2019). S. littoralis is difficult to control due to the resistance developed against synthetic insecticides as well as against Bacillus thuringiensis toxins

\footnotetext{
* Correspondence: wael.elmenofy@ageri.sci.eg

${ }^{1}$ Agricultural Genetic Engineering Research Institute, ARC, Giza 12619, Egypt Full list of author information is available at the end of the article
}

(Ghulam et al. 2017). In addition, the use of chemical insecticide leads to detrimental effects on the natural enemies, pollinators, and all other non-target insects. Moreover, it causes serious toxicological problems to humans, plants, animals, and the whole environment. In order to avoid the risks associated with using chemical pesticides, there is an urgent need to encourage biological control agents as alternatives to chemical pesticides. Many biological agents have been used for the control of insect pests, such as parasitoids, predators, and entomopathogens (bacteria, fungi, and viruses) (El-Gaied et al. 2020 and Atia et al. 2016). Among these biopesticides are baculoviruses, which have been considered to be insect-specific viruses 
that have potential for biological control of insect pests in agriculture as well as an effective eukaryotic protein expression system (Elgaied et al. 2017 and Elmenofy et al. 2020).

Baculoviruses are large, double-stranded DNA viruses that infect arthropods and insects, particularly of the order Lepidoptera, but they also infect the orders Coleoptera, Hymenoptera, and Diptera. They are a promising alternative to chemical pesticides. They are able to kill insect larvae within a few days (Agata et al. 2010). It is assumed that baculoviruses are safe and restricted to invertebrates, where they are specific pathogen for insects (Ahmed et al. 2016). Baculoviruses resort to be species- or genus-specific, although there are some exceptions to this rule, like the Autographa californica nucleopolyhedrovirus (Mahendra and Avinash 2012). S. littoralis nucleopolyhedrovirus (SpliNPV) belongs to the family Baculoviridae. It is one of the most promising biocontrol agents against pests. The host range of the virus has been shown to be narrow, likely infecting within Spodoptera spp. with a relatively slow speed of action. The slow speed of action is one of the major drawbacks of using SpliNPV wild-type isolates as an effective biocontrol agent that can compete with broadspectrum chemical insecticides. In order to solve this problem, developing a new and efficient biocontrol agent is highly important to be used in integrated pest management of $S$. littoralis.

Therefore, the main objective of this work was to study the molecular and the biological characteristics (toxicity effect) of $S$. littoralis baculovirus isolates as candidate virus-based biocontrol agents against pests in Egypt.

\section{Materials and methods}

\section{Insect and viruses}

S. littoralis used for virus propagation and bioassay experiments was derived from the insect-rearing facility of the Agricultural Genetic Engineering Research Institute, Agricultural Research Center, Giza, Egypt. The larvae were maintained at $26^{\circ} \mathrm{C}$ with $60 \% \mathrm{RH}$. Larvae were reared on a semi-artificial diet containing agar-agar, maize meal, wheat germ, brewer's yeast, ascorbic acid, and Nipagien (methyl 4-hydroxybenzoate) previously described by (Ivaldi-Sender 1974). Viruses used in this study were fieldcollected baculovirus isolate genus nucleopolyhedrovirus from infected cadavers from Giza district in Egypt.

\section{Virus propagation in S. littoralis larvae}

The $S$. littoralis larvae (4th instar) were placed in boxes (50-well plate) with a small piece of insect medium. Each piece of media was inoculated with $10^{5}$ of virus occlusion bodies (OBs), then the plates were incubated at $26^{\circ} \mathrm{C}$. The next day, larvae were transferred to virus-free medium and continued rearing until observation of viral infection symptoms (7-10 days post-infection).

\section{Virus purification from infected larvae}

Infected larvae were collected for virus purification according to Boughton et al. (1999). Using 0.1\% SDS, infected larvae were homogenized and the suspension that formed from the grinded larvae was filtered by using a piece of cotton and filter paper. Excess of 0.1\% SDS was added until the filter paper became clear. The grinded tissues containing virus occlusion bodies (OBs) were centrifuged at $7000 \mathrm{rpm}$ for $10 \mathrm{~min}$ at room temperature. The supernatant was discarded, and the pellet was resuspended in $1 \mathrm{ml} 0.5 \%$ SDS/larva using vortex then centrifuged again at $7000 \mathrm{rpm}$ at room temperature for $10 \mathrm{~min}$. The pellets were re-suspended in $0.5 \mathrm{M} \mathrm{NaCl}$ by vortex, then centrifuged again at $7000 \mathrm{rpm}$ for $10 \mathrm{~min}$. The pellets were suspended in a small volume of $d_{d d} \mathrm{H}_{2} \mathrm{O}$ $(0.5 \mathrm{ml} /$ larvae) by pipetting or gentle vortex. The diluted OBs were counted in the dark field of the Axiovert Zeiss inverted microscope with a $\times 200$ magnification, using a Petroff-Hauser counting chamber (depth $0.01 \mathrm{~mm}$, Hausser Scientific). The purified virus was kept frozen at $-20^{\circ} \mathrm{C}$.

\section{Purification of virus DNA}

Using the method developed by Boughton et al. (1999), viral genomic DNAs were isolated from viral OBs. Briefly, about $300 \mu$ l of purified virus OBs was precipitated for $10 \mathrm{~min}$ at $7000 \mathrm{rpm}$, and pellet-containing viral OBs were re-suspended in $200 \mu \mathrm{l}$ of $\mathrm{H}_{2} \mathrm{O} .1 \mathrm{M}$ of $\mathrm{Na}_{2} \mathrm{CO}_{3}$ (sterile filtrated) in the final concentration of $0.1 \mathrm{M}$ was added then incubated for $1 \mathrm{~h}$ at $37^{\circ} \mathrm{C}$ in water bath till the solution became clear. The solution was neutralized with autoclaved $1 \mathrm{M} \mathrm{HCl}$ to $\mathrm{pH} 8$, and $10 \%$ $(w / w)$ SDS solution was added in the final concentration of $1 \%$. Then, proteinase $\mathrm{K}$ was added in the final concentration of $250 \mu \mathrm{g} / \mathrm{ml}$, and the suspension was incubated for $1 \mathrm{~h}$ at $37^{\circ} \mathrm{C}$ to release the nucleic acids. The samples were washed twice with TE buffer-saturated phenol/ chloroform 1:1 (v/v) and one more time with chloroform to remove the phenolic traces. Viral genomic DNA was precipitated using 2.5 volume ice-cold $96 \%$ ethanol and $1 / 10$ volumes $3 \mathrm{M} \mathrm{NaAc}$ pH 5.2 in $-80^{\circ} \mathrm{C}$ and then washed twice with $70 \%$ ethanol. The pellet was dried for $5 \mathrm{~min}$ at RT, then DNA was eluted in a suitable amount of autoclaved water.

\section{Restriction profile analysis}

Restriction digestion of the viral DNA was performed to compare the genome pattern of virus isolates, using ScaI endonuclease. Briefly, $1-1.5 \mu \mathrm{g}$ genomic DNA was digested, using the following component: $9 \mu$ l of viral DNA, $1 \mu \mathrm{l}$ of the appropriate enzyme $(5 \mathrm{U} / \mu \mathrm{l}), 2 \mu \mathrm{l} 10 \times$ 
buffer, and $7 \mu \mathrm{l}$ of $d d \mathrm{H}_{2} \mathrm{O}$. The mixture then was incubated for $2 \mathrm{~h}$ at $37^{\circ} \mathrm{C}$. Electrophoresis was performed overnight, using $0.8 \%$ agarose in 1XTAE buffer $(40 \mathrm{mM}$ Tris, $20 \mathrm{mM}$ acetate, and $1 \mathrm{mM}$ EDTA, $\mathrm{pH}$ 8.6) (Boughton et al. 1999).

\section{PCR amplification of polyhedrin gene}

One set of polyhedrin-specific primers, designed and synthesized based on the reference strain SpliMNPV-AN1956 (Accession No. NC_038369) Breitenbach et al. (2013), was used to partially amplify polyhedrin fragment from each virus genomic DNA. Primers denoted Spli-polh-560_F (5'-ATCTGGGCAAAACCTATGTAT-3') and Spli-polh560_R (CTTGGCGAGACTGATGCGGTATTC). The PCR reactions were performed in a total reaction volume of $50 \mu \mathrm{l}$ containing $1 \mu \mathrm{l}$ of the appropriate upper primer $(10 \mathrm{pmol} / \mu \mathrm{l}), 1 \mu \mathrm{l}$ of the appropriate lower primer (10 $\mathrm{pmol} / \mu \mathrm{l}), 1.5 \mu \mathrm{l} \mathrm{MgCl} 2(50 \mathrm{mM}), 1.5 \mu \mathrm{l}$ of dNTPs mixture solution $(10 \mathrm{mM}), 2 \mu \mathrm{l}$ of DNA template $(0.1-0.5 \mu \mathrm{g}), 5 \mu \mathrm{l}$ of $10 \times$ PCR reaction buffer, and $0.5 \mu \mathrm{l}$ of Taq DNA polymerase $(5 \mathrm{U} / \mu \mathrm{l})$. The reaction volume was completed to $50 \mu \mathrm{l}$, using autoclaved bdH $\mathrm{H}_{2} \mathrm{O}$. For a typical PCR reaction, the following program was used: an initial $95^{\circ} \mathrm{C}$ for $3 \mathrm{~min}$; a total of 30 cycles of denaturation at $95^{\circ} \mathrm{C}$ for $1 \mathrm{~min}$, primer annealing at $59^{\circ} \mathrm{C}$ for $1 \mathrm{~min}$, and primer extension at $72{ }^{\circ} \mathrm{C}$ for $1 \mathrm{~min}$; and a final cycle at $72^{\circ} \mathrm{C}$ for $7 \mathrm{~min}$ to allow the completion of primer extension. PCR-amplified DNA was analyzed by electrophoresis on a $1 \%$ agarose gel prepared in $1 \times$ TAE buffer. The PCR products were purified using the Qiaquick PCR purification kit (Qiagene, Germany). Nucleotide sequences for the purified fragments were performed using the Sanger sequence.

\section{Sequencing and phylogenetic analysis}

Analysis of the polyhedrin-deduced amino acid sequences was performed for both isolates, using EditSeq-DNAstar Inc., Expert Sequence Analysis software, Windows 32 Edit Seq 4.00 (1989-1999), ExPasy database, and Clustal Omega for multiple alignment analysis. Blastp search for alignment of the resulted deduced amino acid sequences with the published ones was carried out, using the database of the National Center for Biotechnology Information (NCBI).

\section{The $\mathrm{LC}_{50}$ and $\mathrm{ST}_{50}$}

To determine the median lethal concentration $\left(\mathrm{LC}_{50}\right)$ for each isolate, 6 different concentrations were prepared for each virus suspension as follows: $10^{3}, 5 \times 10^{3}, 10^{4}, 5$ $\times 10^{4}, 10^{5}$, and $5 \times 0^{5} \mathrm{OBs} / \mathrm{ml}$, in addition to the control solution, which contains $\mathrm{ddH}_{2} \mathrm{O}$ instead of virus suspension. Two plates (50-well) were used for each experiment in addition to 2 plates for the control treatment. The volume of each virus concentration was completed to $10 \mathrm{ml}$ with water and added to $90 \mathrm{ml}$ larval media $\left(40^{\circ} \mathrm{C}\right)$ that were prepared in advance, then the mixture of media and virus suspension was poured on the plates. After solidification, larvae were added to all plates and incubated for $24 \mathrm{~h}$, then handling error was taken by counting the dead larvae. After 7 days, dead larvae were counted and the $\mathrm{LC}_{50}$ were analyzed, using EPA Probit analysis program (version 1.5). Another way of infection was introduced using a mixed infection by mixing Spli-6 and Spli-7. An equal volume of each isolate OBs was added to the mixture. This mixture was used to prepare serial dilution of virus-infected inoculum that was used to infect larvae in a bioassay experiment as mentioned before. Moreover, the median survival time $\left(\mathrm{ST}_{50}\right)$ was determined by inoculating 50 individually held larvae in 3 replicates with the calculated $\mathrm{LC}_{80}$ for each tested virus, as well as 2 control plates, which were mixed by water instead of virus suspension. The mortality of the larvae was monitored every $24 \mathrm{~h}$, starting day 3 postinfection until day 7 or larval death. Data analysis was performed, using the Kaplan-Meier survival time estimator analysis (Kaplan-Meier 1958).

\section{Results and discussion \\ Viruses' isolation and propagation}

In this study, two baculovirus isolates denoted Spli-6 and Spli-7 were characterized. Both isolates were obtained from diseased $S$. littoralis larvae and exhibited viral-like symptoms which were collected from Giza district in Egypt. Viral symptoms of collected infected S. littoralis were slow motion and visibly swollen by fluid containing the virus; similar results were reported by Toprak et al. 2005 and Ahmed et al. 2016. Both isolates were further propagated, using $S$. littoralis 4th instar larvae, reared on a semi-artificial diet. Typical viral infection symptoms were detected in infected $S$. littoralis larvae 7-8 days postinfection, suggesting that these isolates were baculovirusspecific isolates to S. littoralis (Fig. 1). The total counting of polyhedral for each isolate was as follows: $1.1 \times 10^{7}$ $(\mathrm{OBs} / \mathrm{ml})$ and $1.7 \times 10^{8}(\mathrm{OBs} / \mathrm{ml})$ for Spli-6 and Spli-7, respectively. Using insect-specific viruses is an effective active ingredient for the development of biopesticides in the agricultural field for the control of different insect pests (Cory et al. 2005). The NPVs, belonging to baculoviruses family, are well known for their genetic evolution, higher genetic variation, and differences in their potency. These factors remain conserved even when the baculovirus isolates are purified from the same species of different geographical locations (Cory et al. 2005).

\section{PCR amplification of polyhedrin gene}

Viral genomic DNA was purified, using OBs of each isolate (Spli-6 and Spli-7). As shown in Fig. 2a, about 200$500 \mathrm{ng}$ of each purified genomic DNA was examined in agarose gel to check DNA quality. Enough amount of genomic DNA was successfully purified from each 


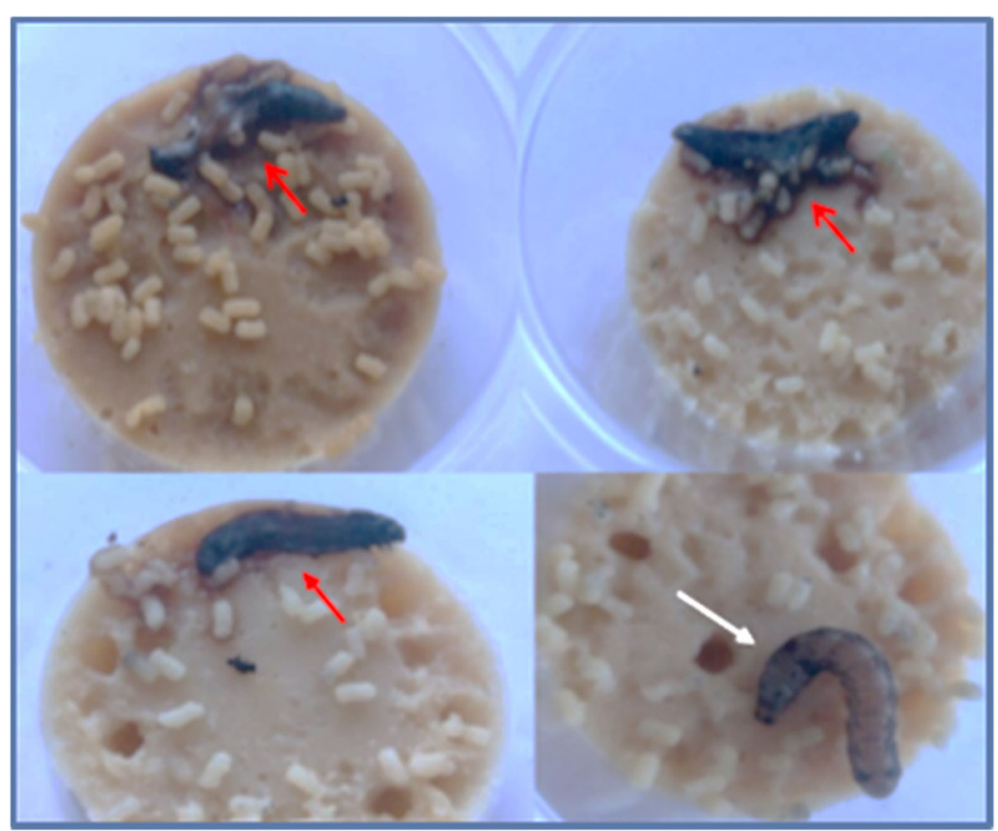

Fig. 1 Photos showing the differences between infected Spodoptera littoralis 4th instar larvae (pointed by red arrows) and healthy larva (pointed by a white arrow) about 7 days post-infection. The infected $S$. littoralis larvae became visibly swollen with fluid containing the virus and turned black with decay

isolate and was used for the downstream work. PCR was performed to partially amplify a specific fragment of polyhedrin gene (polh). As shown in Fig. 2b, the amplified fragments give the expected size of polh gene of about $560 \mathrm{bp}$, which subsequently subjected to Sanger nucleotide sequencing. Primers specific for polyhedrin gene were used in this study for Egyptian NPV virus detection and identification by PCR as well as phylogenetic analysis, since it is highly conserved between NPVs (Jehle et al. 2006). Thus, the polyhedrin (polh) gene was partially amplified to determine the nucleotide sequence for both isolates to be compared to other NPVs corresponding to sequences available in GenBank.

\section{Phylogenetic analysis}

The partial coding sequence of the polh gene was obtained and compared to another polh gene from NPVs, using the polh-deduced amino acids. The results of these analyses are shown in Fig. 3. The results showed that the sequence ( $500 \mathrm{bp}$ ) of both isolates Spli-6 and Spli-7 was closed and had a common ancestor to the sequence of polyhedrin gene, from an Egyptian Spodoptera littoralis nucleopolyhedrovirus isolate SpliNPV-4375, with accession no. AAR04375.1, as well as the sequence of S. littoralis NPV isolate 1263 polyhedrin (polh) gene, partial cds with accession number AGE90003.1. The phylogenic tree was constructed from the deduced amino acids via the Clustal

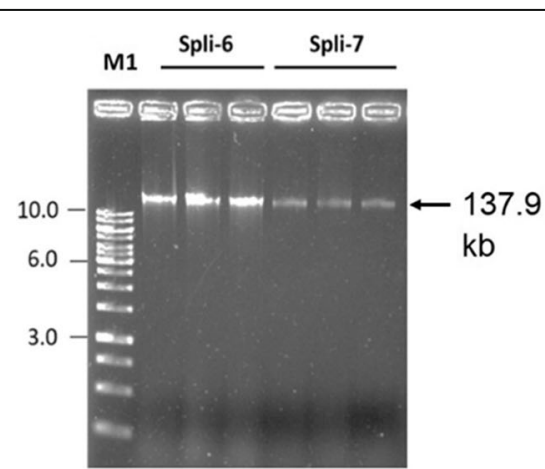

a

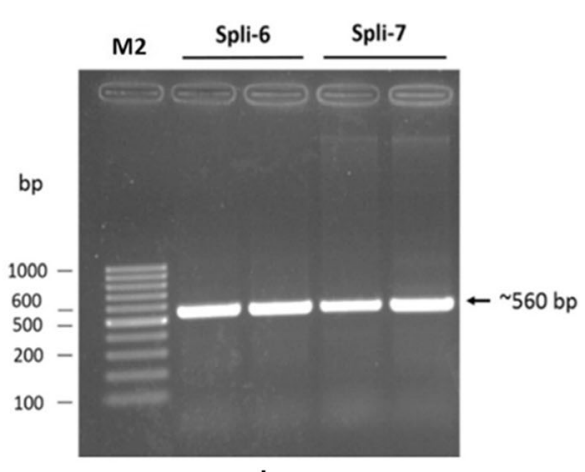

b

Fig. 2 a Agarose gel of $0.8 \%$ in TAE represents genomic DNA (137.9 kb) purified from occlusion bodies of nucleopolyhedrovirus isolates Spli-6 and Spli-7. b Partial amplification of polh gene by PCR using gene-specific primers. Spli-6 and Spli-7 isolated genomic DNA were used as a template for polh amplification for each PCR product separately. M1 represents 1-kb ladder. M2 represents 100-bp DNA ladder 


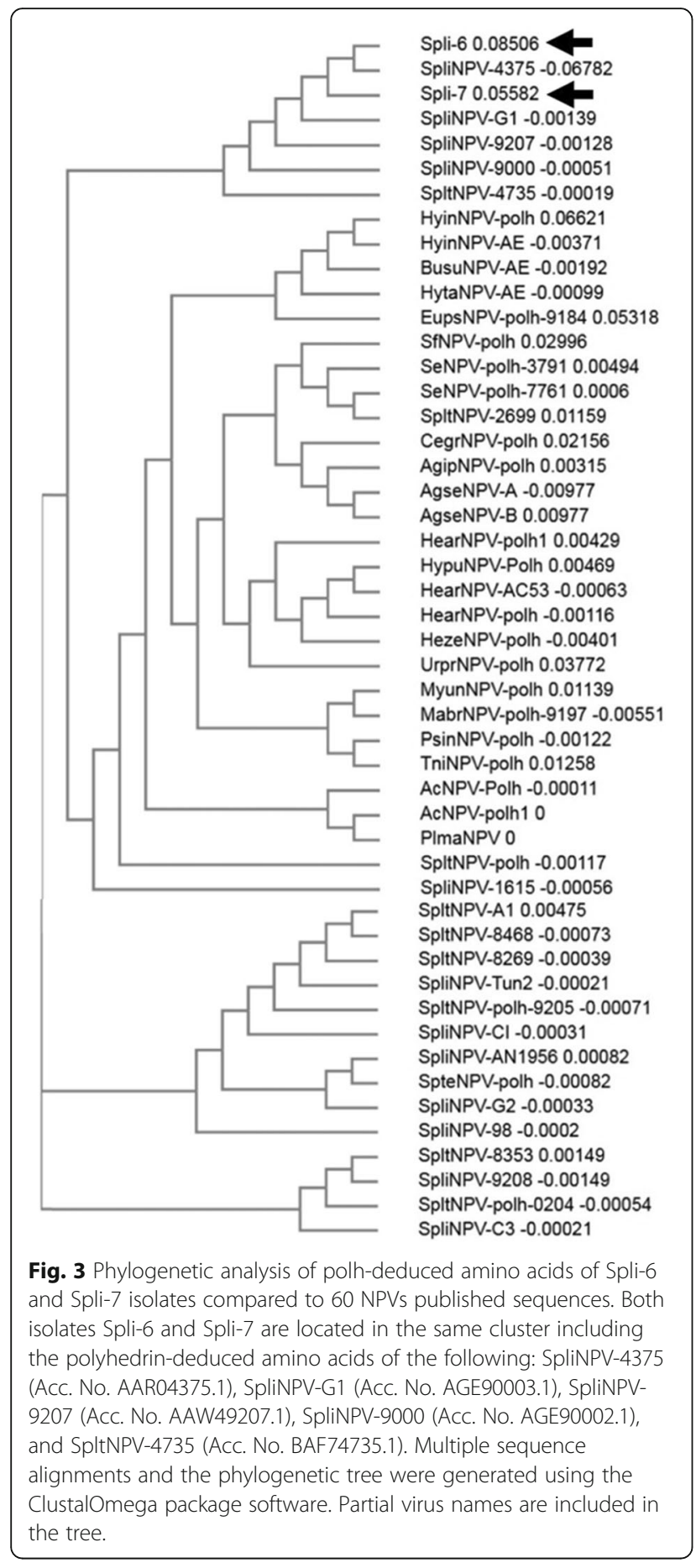

Omega (Sievers et al. 2011) used in the mBed algorithm (Blackshields et al. 2010). The phylogenetic tree showed that Spli-6 was more closed to the isolate Spli- 4375 compared to Spli-7; however, both isolates are located in the same cluster, which belongs to nucleopolyhedrovirus group II (NPV II) (Herniou and Jehle 2007). Based on the distance to these viruses, SpliNPV-Spli6 and SpliNPVSpli7 may be regarded as a variant virus isolates from the reference isolate SpliNPV-AN1956 previously published by Breitenbach et al. (2013).

\section{Analysis of virus DNA}

The genomic DNA of each virus isolate was cleaved by the enzyme ScaI, to compare restriction profiles generated among them. The analyses were performed by comparison of additional fragments present in relation to the number of fragments common to both isolates generated by each cleavage. This also was compared to the restriction profile of the reference strain SpliNPVAN1956 (accession number: JX454574). Digestion with ScaI resulted in a characteristic DNA profile for isolate Spli-7, as indicated by the presence of the marker fragments $(\sim 25, \sim 19,5.8$, and $5.3 \mathrm{kbp}$ for isolate Spli-7; Fig. 4, lane C), absent in the corresponding profile of the isolate Spli-6 as well as the reference isolate SpliNPVAN1956. While it seems that some ScaI fragments of about $\sim 13 \mathrm{kbp}$ and $8.5 \mathrm{kbp}$ were missed in the Spli-7 profile, the fragment intensity was low in Spli-7 compared to Spli-6 and the reference strain. Overall, REN profiles contained a number of submolar bands indicating that Spli7 isolate comprised a genotypic variant.

\section{Median lethal concentration}

In order to test the biological activity of SpliNPV virus isolates, their median lethal concentration $\left(\mathrm{LC}_{50}\right)$ was determined. The analysis showed that $\mathrm{LC}_{50}$ value of Spli-7 $\left(9.5 \times 10^{4} \mathrm{OBs} / \mathrm{ml}\right)$ was higher than that of Spli-6 $\left(3 \times 10^{4} \mathrm{OBs} / \mathrm{ml}\right)$. Interestingly, the calculated $\mathrm{LC}_{50}$ for the mixed infection between both isolates was $3.9 \times 10^{4}$ OBs/ml (Table 1). The results showed that Spli-6 had the best virulence then the combination of both isolates and Spli-7 being the lowest based on $\mathrm{LC}_{50}$ values.

\section{Median survival time}

The $\mathrm{ST}_{50}$ was calculated, using the Kaplan-Meier survival time estimator analysis (Table 2). The calculated $\mathrm{ST}_{50}$ values were $96 \mathrm{~h}$ for Spli-6, $96 \mathrm{~h}$ for Sli-7, and $120 \mathrm{~h}$ for mixed infection. As shown in Fig. 5, the observed survival plots for the tested viruses (Spli-6 and Spli-7) were closed to each other. Non-significant difference was observed between the tested Spli-6 and Spli-7 survival curves, which had the same speed of killing. During the bioassays, no differences were observed in the disease symptoms of the $S$. littoralis larvae infected either with Spli-6, Spli-7, or the mixed infection. However, the calculated $\mathrm{ST}_{50}$ of the mixed infection was significantly higher than that of each single infection with about $24 \mathrm{~h}$.

Unexpectedly, the calculated $\mathrm{LC}_{50}$ of SpliMNPV isolates against $S$. littoralis 1 st instar larvae were $3.0 \times 10^{4}$ $\mathrm{OBs} / \mathrm{ml}$ and $9.5 \times 10^{4} \mathrm{OBs} / \mathrm{ml}$ for Spli-6 and Sli-7, respectively. They were relatively higher than that observed $\mathrm{LC}_{50}\left(1 \times 10^{3} \mathrm{OBs} / \mathrm{ml}\right)$ for the 1 st instar $S$. litura 


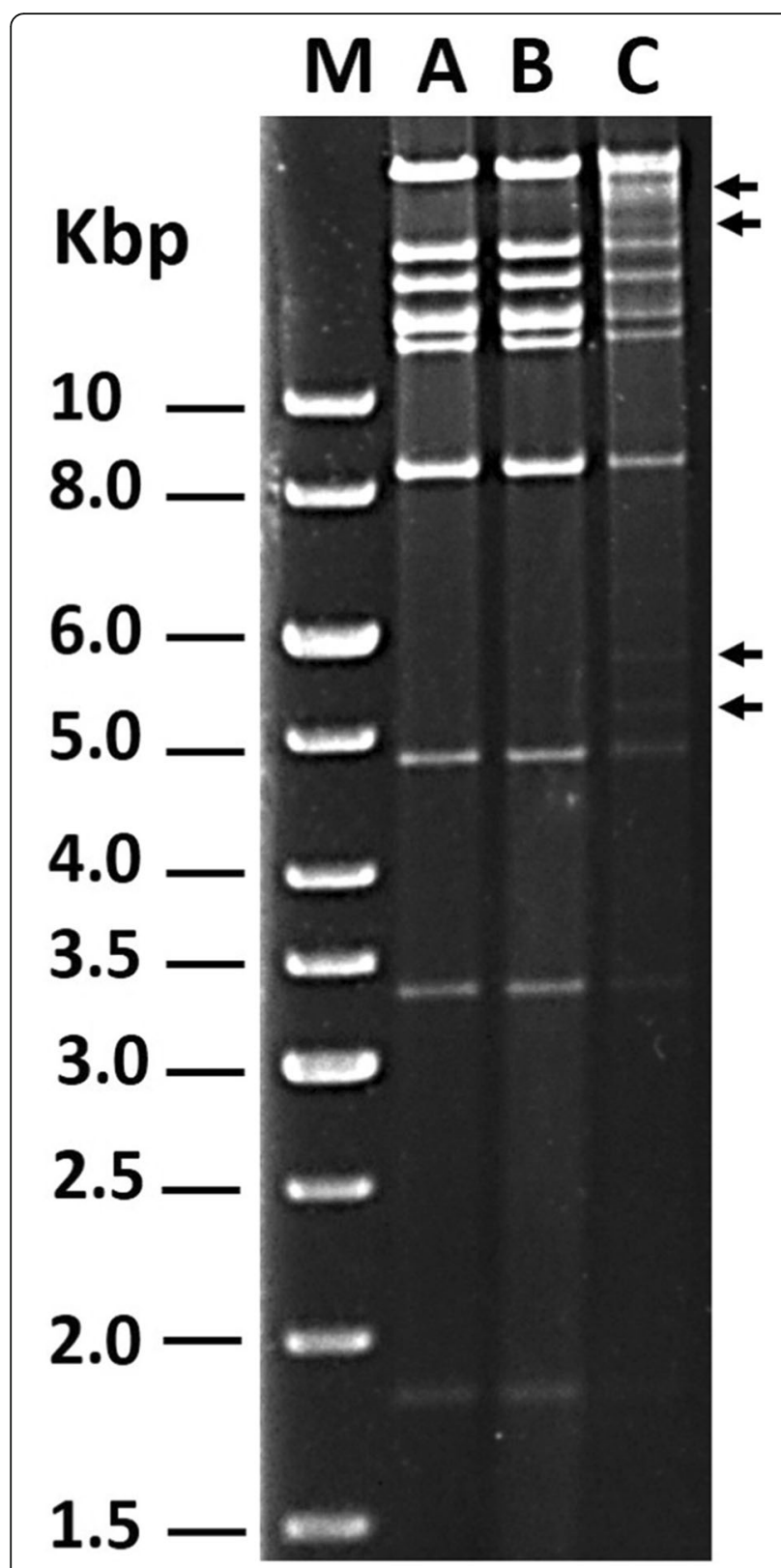

Fig. 4 Comparison of DNA restriction profile patterns among Spodoptera littoralis nucleopolyhedrovirus isolates (Spli-6 and Spli-7) after digestion using Scal endonuclease compared to the pattern of the reference strain. Lane A, reference strain SpliNPV-AN1956; lane B, isolate Spli-6; and lane C, isolate Spli-7. Fragments were separated by electrophoresis in $0.8 \%$ agarose gel in 1\% TAE. Each novel band is marked by a black arrow. M: 1-kb DNA ladder (Thermo Fisher)

larvae by using S. litura NPV isolate (Trang and Chaudhari 2002). In the same context, according to Kumar et al. (2011), the finding was very close to the $\mathrm{LC}_{50}$ of the 2 different SpltNPV virus-specific isolates, which were $3.5 \times 10^{4}$ and $2.4 \times 10^{5} \mathrm{OBs} / \mathrm{ml}$ against $S$. litura 2nd and 3rd larval instars, respectively. The $\mathrm{ST}_{50}$ for both isolates was $96 \mathrm{~h}$, which was higher than the $\mathrm{ST}_{50}$
Table 1 Median lethal concentration $\left(L C_{50}\right)$ of 1st instar $S$. littoralis larvae infected either with Spli-6, Spli-7, or mixed viruses 7 days post-infection

\begin{tabular}{lllll}
\hline Virus & No. of larvae & $\left.L_{50}(\mathrm{OBs} \mathrm{m})^{-1}\right)(\mathrm{Cl})$ & Slope $(\mathrm{SE})$ & $X^{2}$ \\
\hline Spli-6 & 718 & $3.0 \times 10^{4}\left(2.4 \times 10^{4}-3.7 \times 10^{4}\right)$ & $2.18(0.22)$ & 9.4 \\
Spli-7 & 526 & $9.5 \times 10^{4}\left(7.5 \times 10^{4}-1.2 \times 10^{5}\right)$ & $1.68(0.20)$ & 7.8 \\
Mixed & 707 & $3.9 \times 10^{4}\left(7.1 \times 10^{3}-3.1 \times 10^{5}\right)$ & $1.58(0.45)$ & 9.4
\end{tabular}

The $\mathrm{LC}_{50}$ of probit analysis, as well as the slopes of the probit lines, are given Cl 95\% confidence interval, SE standard error

of some SpliMNPV isolates presented by Toprak et al. (2005), which ranged from $72-84 \mathrm{~h}$ against $S$. littoralis larvae. However, it was less than that observed for SpliMNPV isolates, which ranged from 125 to $360 \mathrm{~h}$ (Lacey et al. 2015). On the same context, the calculated $\mathrm{ST}_{50}$ value of isolate Spli-6 and Spli-7 was higher than that of SpltNPV-Pak-BNG that was $84 \mathrm{~h}$ but lower than SpltNPV-G1, which was $108 \mathrm{~h}$ against the 3rd instar $S$. litura larvae (Ghulam et al. 2017). The high virulence of both isolates (Spli-6 and Spli-7) to S. littoralis may suggest their potential as a promising viral bioinsecticide. However, the mixed infection between both isolates did not affect the potency of the isolates based on the virulence parameters $\left(\mathrm{LC}_{50}\right.$ and $\left.\mathrm{ST}_{50}\right)$ than to each single isolate. This observations suggested that the speed of killing of the tested isolates against the S. littoralis larvae may vary based on the collected district and the target insect host. The calculated virulence parameters for both isolates suggested the suitability of the Egyptian environment for collecting new baculovirus isolates that can be used as an active ingredient for the development of new formulated products for effective control of $S$. littoralis. Given that baculoviruses were isolated from Giza district in Egypt, where most of the crops usually received chemical insecticides, it would be expected to find more isolates in the regions where no insecticides are used.

\section{Conclusion}

In the present study, two different S. littoralis nucleopolyhedrovirus (SpliNPV) isolates, denoted as Spli-6 and Spli-7, were obtained from natural infected S. littoralis larvae in Egypt. The Spli-6 significantly showed higher virulence toward S. littoralis 1st instar larvae than Spli-7 as well as the mixed infection. However, both isolates showed the same speed of killing of $96 \mathrm{~h}$ based on the

Table 2 Kaplan-Meier estimation of $\mathrm{ST}_{50}$ of S. littoralis larvae infected with OBs derived from Spli-6, Spli-7, and mixed viruses

\begin{tabular}{lllll}
\hline Virus & No. of larvae & $\mathrm{LC}_{80}(\mathrm{OB} / \mathrm{ml})$ & $\mathrm{ST}_{50}$ & $\mathrm{Cl}$ (lower-upper) \\
\hline Spli-6 & 103 & $9.05 \times 10^{4}$ & 96 & $86-105$ \\
Spli-7 & 109 & $3.93 \times 10^{5}$ & 96 & $90-101$ \\
mixed & 97 & $1.75 \times 10^{5}$ & 120 & $109-130$ \\
\hline
\end{tabular}

$\mathrm{ST}_{50}$ and $95 \%$ confidence interval $(\mathrm{Cl})$ are given in hours post-infection (hpi) 


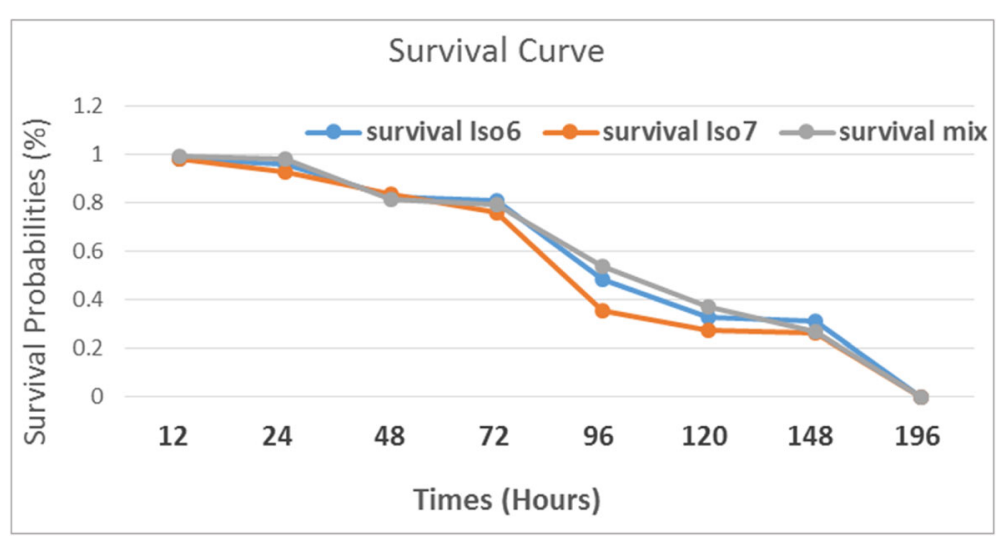

Fig. 5 Survival curves using the StatsDirect statistical analysis software Kaplan-Meier. Graph showing the survival time analysis of SpliNPV isolates: Spli-6, Spli-7, and the mixed infection as observed on infected Spodoptera littoralis larvae

$\mathrm{ST}_{50}$ value. The phylogenetic analysis of the partial deduced amino acid sequence of polyhedrin gene (polh) showed that both isolates were closed and have a common ancestor with S. littoralis NPV isolate 1263 polyhedrin (polh) gene, partial cds contains accession number AGE90003.1 that belongs to group II NPVs. The high virulence of both isolates (Spli-6 and Spli-7) to $S$. littoralis may suggest their potential as a promising viral-based bioinsecticide for the control of $S$. littoralis in Egypt.

\section{Abbreviations}

$\mathrm{LC}_{50}$ : Median lethal concentration; NPVs: Nucleopolyhedroviruses;

OBs: Occlusion bodies; PCR: Polymerase chain reaction; polh: Polyhedrin; REN: Restriction endonuclease; S. littoralis: Spodoptera littoralis; Spli-6: SpliNPV isolate Spli-6; Spli-7: SpliNPV isolate Spli-7; SpliNPV: Spodoptera littoralis nucleopolyhedrovirus; ST $_{50}$ : Median survival time; TAE: Tris-acetate-EDTA

\section{Acknowledgements}

Not applicable

\section{Authors' contributions}

WE put the idea, designed the experiments, and wrote and revised the manuscript. LE and El collected the field samples and restriction pattern analysis as well as shared in manuscript writing. NY, SA, AE, and AE did the molecular biology work as well as the bioassay experiments. AA, MS, and AZ reared S. littoralis larvae and virus isolate propagation. RS, EH, and ST designed the bioassay experiments and analysis of the data. All authors read and approved the final manuscript.

\section{Funding}

This work was funded in a collaboration project between the Department of Biotechnology/BioMolecular Chemistry Concentration Faculty of Science, Cairo University; Agricultural Genetic Engineering Research Institute, ARC; and the Academy of Scientific Research \& Technology (Project ID: 1490).

\section{Availability of data and materials}

Not applicable

\section{Ethics approval and consent to participate}

Not applicable

\section{Consent for publication}

Not applicable

\section{Competing interests}

We declare that we have no competing interests.

\section{Author details}

${ }^{1}$ Agricultural Genetic Engineering Research Institute, ARC, Giza 12619, Egypt. Biotechnology/BioMolecular Chemistry Concentration, Faculty of Science, Cairo University, Giza, Egypt. ${ }^{3}$ Department of Genetics, Faculty of Agriculture, Cairo University, Giza, Egypt.

Received: 31 March 2020 Accepted: 1 June 2020

Published online: 16 June 2020

\section{References}

Agata KJ, Dwight EL, Herrero S, Vlak JM, van Oers MM (2010) Host-range expansion of Spodoptera exigua multiple nucleopolyhedrovirus to Agrotis segetum larvae when the midgut is bypassed. J Gen Virol 91:898-906

Ahmed YE, Desoky SM, El-Sabagh MM, Sofy AR (2016) Molecular and biological characterization of a nucleopolyhedrovirus isolate (Egy-SINPV) from Spodoptera littoralis in Egypt. Int J Virol Mol Bio 5:34-45

Atia MA, Osman GH, Elmenofy WH (2016) Genome-wide in silico analysis, characterization and identification of microsatellites in Spodoptera littoralis multiple nucleopolyhedrovirus (SpliMNPV). Sci. Rep. 6:33741. https://doi.org/ 10.1038/srep33741

Blackshields G, Sievers F, Shi W, Wilm A, Higgins DG (2010) Sequence embedding for fast construction of guide trees for multiple sequence alignment. Algorithms Mol Biol 5:21-30

Boughton AJ, Harrison RL, Lewis LC, Bonning BC (1999) Characterization of a nucleopolyhedrovirus from the black cutworm, Agrotis ipsilon (Lepidoptera: Noctuidae). J Invertebr Pathol 74:289-294

Breitenbacha JE, El-Sheikha A, Rb H, Rowleyb DL, Sparksb ME, Gundersen-Rindalb DE, Popham HJR (2013) Determination and analysis of the genome sequence of Spodoptera littoralis multiple nucleopolyhedrovirus. Virus Res 171:194-208

Cory JS, Green BM, Paul RK, Hunter-Fujita F (2005) Genotypic and phenotypic diversity of a baculovirus population within an individual insect host. J Invertebr Pathol 89:101-111

El-Gaied L, Mahmoud A, Salem R, Elmenofy W, Saleh I, Abulreesh H, Arif I, Osman G (2020) Characterization, cloning, expression and bioassay of vip3 gene isolated from an Egyptian Bacillus thuringiensis against whiteflies. Saudi J Biol Sci 27:1363-1367. https://doi.org/10.1016/j.sjbs.2019.12.013

Elgaied L, Salem R, Elmenofy W (2017) Expression of tomato yellow leaf curl virus coat protein using baculovirus expression system and evaluation of its utility as a viral antigen. 3 Biotech 7:269. https://doi.org/10.1007/s13205-017-0893-4

Elmenofy W, Mohamed I, El-Gaied L, Salem R, Osman G, Ibrahim M (2020) Expression of $1 \mathrm{~B}$ capsid protein of foot-and-mouth disease virus (FMDV) using baculovirus expression system and its validation in detecting SAT 2specific antisera. Peer J 8:e8946. https://doi.org/10.7717/peerj.8946 
Ghulam A, van der Wopke W, Vlak JM (2017) Biological and genetic characterization of a Pakistani isolate of Spodoptera litura nucleopolyhedrovirus. Biocontrol Sci Technol 28:20-33

Herniou EA, Jehle JA (2007) Baculovirus phylogeny and evolution. Curr Drug Targets 8:1043-1050

Hosny MM, Topper CP, Moawasd GG, El-Saadany GB (1986) Economic damage threshold of Spodoptera littoralis (Boisd.) (Lepidoptera: Noctuidae) on cotton in Egypt. Crop Prot 5:100-104

Ivaldi-Sender C (1974) Techniques simples pour élévage permanent de la tordeuse orientale, Grapholita molesta (Lep., Tortricidae), sur milieu artificiel. Ann Zool Ecol Anim 6:337-343

Jehle JA, Lange M, Wang H, Hu Z, Wang Y, Hauschild R (2006) Molecular identification and phylogenetic analysis of baculoviruses from Lepidoptera. Virology 346:180-193

Kaplan-Meier (1958) Nonparametric estimation from incomplete observations. J Amer. Stat. Associ 53:457-481

Kumar CS, Ranga Rao GV, Sireesha K, Kumar LP (2011) Isolation and characterization of baculoviruses from three major lepidopteran pests in the semi-arid tropics of India. Indian J Virol 22:29-36

Lacey LA, Grzywacz D, Shapiro-llan DI, Frutos R, Brownbridge M, Goettel M (2015) Insect pathogens as biological control agents: back to the future. J Invert Pathol 132:1-41

Mahendra R, Avinash I (2012) Role of nanotechnology in agriculture with special reference to management of insect pests. Appl Microbiol Biotechnol 94:287-293

Mohamed HA, Alkordy, Atta AA (2019) Effect of host plants on biology of Spodoptera littoralis (Boisd.). Egypt Acad J Biolog Sci 12:65-73

Sievers F et al (2011) Fast, scalable generation of high-quality protein multiple sequence alignments using Clustal Omega. Mol Syst Biol 7:539

Toprak U, Bayram S, Gürkan MO (2005) Gross pathology of SpliNPVs and alterations in Spodoptera littoralis Boisd. (Lepidoptera: Noctuidae) morphology due to baculoviral infection. Tarim Bilimleri Dergisi 11:65-71

Trang T, Chaudhari S (2002) Bioassay of nuclear polyhedrosis virus (NPV) and in combination with insecticide on Spodoptera litura (Fab). OmonRice 10:45-53

\section{Publisher's Note}

Springer Nature remains neutral with regard to jurisdictional claims in published maps and institutional affiliations.

\section{Submit your manuscript to a SpringerOpen ${ }^{\circ}$ journal and benefit from:}

- Convenient online submission

- Rigorous peer review

- Open access: articles freely available online

- High visibility within the field

- Retaining the copyright to your article

Submit your next manuscript at $\boldsymbol{\nabla}$ springeropen.com 